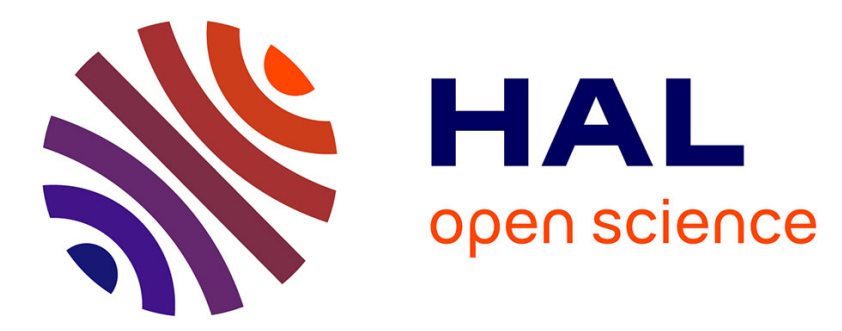

\title{
Unstable rock slope hydrogeology: insights from the large-scale study of western Argentera-Mercantour hillslopes (South-East France)
}

Stéphane Binet, Yves Guglielmi, Catherine Bertrand, Jacques Mudry

\section{To cite this version:}

Stéphane Binet, Yves Guglielmi, Catherine Bertrand, Jacques Mudry. Unstable rock slope hydrogeology: insights from the large-scale study of western Argentera-Mercantour hillslopes (South-East France). Bulletin de la Société Géologique de France, 2007, 178 (2), pp.159-168. hal-00385382

\section{HAL Id: hal-00385382 https://hal.science/hal-00385382}

Submitted on 25 Aug 2011

HAL is a multi-disciplinary open access archive for the deposit and dissemination of scientific research documents, whether they are published or not. The documents may come from teaching and research institutions in France or abroad, or from public or private research centers.
L'archive ouverte pluridisciplinaire HAL, est destinée au dépôt et à la diffusion de documents scientifiques de niveau recherche, publiés ou non, émanant des établissements d'enseignement et de recherche français ou étrangers, des laboratoires publics ou privés. 
Unstable rock slope hydrogeology: insights from the large-scale study of western Argentera-Mercantour hillslopes (South-East France)

\section{STÉPHANE BINET1, YVES GUGLIELMI2, CATHERINE BERTRAND1 et JACQUES MUDRY1}

1. 'Geosiences Besançon', EA 2632 UFC, 16 Route de Gray, F-25030 Besançon, France. E-mail: stephane.binet@univ-fcomte.fr

2. 'Géosciences Azur', UMR 6526 CNRS-UNSA-IRD, 250 Rue Albert Einstein, F-06560, Valbonne SophiaAntipolis, France.

Key words. - Large rocky landslide, Hydrogeology, Groundwater chemistry, Hydro-mechanics

Abstract. - Inventory of unstable hillslopes, hydrogeological mapping and hydrochemical characteristics of natural spring waters were used to determine the long-term relationships between groundwater and gravitational instabilities in the Upper Tinée Valley (South-East French Alps). Water chemistry and flow records allow to propose a conceptual model of water flow within unstable rocky slopes and to back-calculate the volume of infiltrated water and the flow velocity in the aquifers for different deformation states of the slopes. An increase in infiltrated yield, flow velocity and porosity is observed and linked to collapsed and toppled structures in the upper parts of the hillslopes. In these areas, perched aquifers take place in the reworked media. When a large landslide occurs, it modifies the geometry of the slope and bypasses the perched flows down to the foot of the slope. With long-term continuous slope deformation, the associated effect between water flows and slope destabilization changes. In the fractured rock, the coupled effect corresponds to rising water pressures with limited volumes of infiltrated water; in the more fractured and permeable collapsed and toppled areas, the volumes of infiltrated water increase with a lower variation of water pressures.

\section{INTRODUCTION}

In mountainous environments, fractured rock slopes are often affected by decompression since the last glaciation period as can be clearly observed in the field through geomorphological structures like counterscarps or trenches [Julian and Anthony, 1996]. This decompression is followed by the formation of new failure surfaces and generates deep-seated deformation (DSD) and landslides [Cruden and Varnes, 1996], like for the "Valfurna" landslide [Agliardi et al., 2001] or for the "Rosone" unstable hillslope [Forlati et al., 2001]. Several geomechanical studies showed that the main controlling factors of these deformations are the geological structure, the strong toe slope-gradient and the water seepage conditions. The coupling between water pressures and landslide kinematics has been demonstrated on large landslides [Vengeon, 1998; Bonzanigo et al., 2001; Forlati et al., 2001; Cappa et al., 2004]. In the fractured rocks, flow anisotropy combined with regional topographic effects can produce a important increase in water pressure with a strong hydro-mechanical coupling [Bonzanigo et al., 2001]. The seasonal variations of water saturation can progressively load the hillslopes and potentially conduct to destabilization [Tullen, 2002]. The location and rate of water infiltration play a significant role in the hydro-mechanical behaviour [Cappa et al., 2004]. However, the DSDs evolve very slowly and add a temporal evolution to the geometry and hydrogeological characteristics of the aquifer that can modify groundwater flows. The water pressure distribution in the hillslope is therefore in constant evolution.

The water has a long-term and indirect effect on destabilization that creates a complex coupling between water and deformation. For instance at "Zentoku" landslide, the movement induces underground erosion and the groundwater transports the destructured rocks that increase the brittleness of the slope and hence control the kinematics [Furuya et al., 1999] In the "Shek Kip Mei" landslides, geochemical investigations reveal that the slip surfaces have signatures distinct from their parent materials due in part to chemical water alterations [Wen et al., 2004]. These interactions between deformation, rock and water induce long-term hydro-mechanical interactions superimposed to the seasonal water pressures fluctuations. To approach this long-term effect between groundwater flows and slope destabilization at several spatial and temporal scales, a multi-scale flows analysis was carried out in representative unstable areas of the South-East French Alps.

\section{METHODOLOGY USED TO ANALYSE UNSTABLE HILLSLOPE HYDROGEOLOGY}

Geomorphologic, geologic and hydrogeological context of the study area

The study area reaches $3030 \mathrm{~m}$ at the Ténibre Mount which is the highest summit of the Mercantour massif cut by the narrow valley of the Tinée River, with inclinations larger than 30o [Julian and Anthony, 1996]. Many unstable areas are located on these abrupt slopes (fig. 1a). One of these landslides is the noticeable "La Clapière" landslide on the left bank of the valley; this landslide presents a $1 \mathrm{~km}$ wide disturbed rock mass extending from $1100 \mathrm{~m}$ to $1850 \mathrm{~m}$ in elevation (fig. 1a). The Tinée valley was dug since the lower Pliocene [Bigot- Cormier et al., 2000]. Then, the glaciers covered the valley with a maximum thickness estimated to $600 \mathrm{~m}$ until 18000 
years ago [Dubar and Stephan, 2001]. The Mercantour massif consists of granitic and gneissic rocks, covered by Jurassic limestones. Permian sandstones and slates, Triassic quartzites and evaporitic rocks crop out in the valley. Fractures have affected both the basement and the overlying sediment cover [Faure-Muret, 1955]. Faults and joints of various types and related to several tectonic phases have resulted in highly fragmented rock masses [Julian and Anthony, 1996]. At the valley scale, the two main directions of fractures are N020o and N080o Delteil et al., 2003]. These fractured rock slopes are submitted to a pronounced spatial and temporal variation of precipitations. Rock glaciers, observed over 2500 m [Julian and Anthony, 1996], may increase superficial water storage and delay the infiltration [Dysli, 1998]. Thus, the local variation of meteorological parameters induces a complex spatial distribution of infiltrating zones and a delayed infiltration in the aquifer system [Guglielmi et al., 2002]. Slope aquifers can cover considerable ranges of elevation that induce (i) a high rainfall gradient versus elevation during the rain events (Summer storms and Autumn rainfalls), (ii) a quick evolution of the 0oC isotherm position and the snow front during Winter [Verbunt et al., 2003] and, (iii) a shallow storage in Winter. In fractured gneissic hillslopes, the hydraulic conductivity is very low and ranges from about 10-7 to 10-11 m.-1 [Maréchal, 1998] and the water flows into discontinuities of the rock. The inter-connections of the fractures originate mainly from polyphased tectonics. Averaged hydraulic conductivity of the rock is increasing with the decrease of the compression stress [Maréchal, 1998]. Closer to the surface [Maréchal, 1998; Jiao and Malone, 2000] a perched saturated zone is often nested in highly weathered gneisses.

\section{Methodology}

This study will compare several unstable areas located in the Upper Tinée Valley (South-East French Alps) here many landslides are currently active and submitted to the same climatic conditions [Julian and Anthony, 1996]. In the entire Tinée valley, the rock is mainly composed of gneiss, the slope of the valley bottom reaches 450 and the fracturation is controlled by $\mathrm{N} 020 \mathrm{oE}$ and $\mathrm{N} 100 \mathrm{oE}$ directions. The geomorphological map (fig. 1a) indicates a generalized decompressed area bounded by large landslides. Actually, the hillslope cross-sections can be nterpreted as the result of a long-term evolution caused by DSDs and weathering that allow to discuss the long term hydro-mechanical interactions.

\section{Location of springs, water reservoirs and main geomorphological forms}

A detailed geomorphological and hydrogeological mapping of the Tinée Valley was realised. First, the gravitational movements and the geomorphic forms were mapped at a 1:50,000 scale. Second, a hydrogeological map was realized after an inventory of the springs and was correlated to the geomorphological map.

\section{Origin of infiltrated water}

Hydro-geochemistry is a method [Vengeon, 1998; Guglielmi et al., 2002; Tullen, 2002] that allows to build conceptual model of underground water flows [Meijer, 2002] in anisotropic and heterogeneous systems because it records global contrast within the system [Blavoux and Mudry, 1983; Mudry, 1987]. On the "La Clapière" landslide, the chemical approach has improved the knowledge of the relationship between infiltrated water and the landslide kinematics [Cappa et al., 2004; Guglielmi et al., 2005].

To study groundwater flows, an instantaneous physical and chemical analysis of several springs has been performed during the 2003 low groundwater period. Ten profiles were sampled from the bottom of the valley to the mountain top in order to get a representative sampling of the water chemistry variation. 248 springs were localized and 92 of them were sampled. Analysis of some unstable zones compared to observations of the total valley gives a multi-scale approach from $10 \mathrm{~m}$ to $70 \mathrm{~km}$.

\section{Estimation of infiltration characteristics in different geomorphological contexts}

The infiltration characteristics of the aquifers are estimated from yield and chemical content of several springs monitored over time: the flow from a fracture to a gallery under $100 \mathrm{~m}$ of overburden gneiss ("Valabres" hillslope) was taken as representative of flows in unweathered fractured gneiss. Two springs draining a decompressed area (fig. 1b, spring no 43 and no 179) and two springs located at the foot of "La Clapière" landslide (fig. 2b; spring no14 and no15) are monitored to estimate the hydraulic reactions to rainfall events in an active large landslide. The specific yield is the ratio between low water period yield and the estimated surface of the infiltration area; it gives an idea of the amount of water infiltrated in the hillslope. Dilution curves, linked to fresh water flows in the slope, allow to estimate the volume of water drained by the spring during a flood and the average flow velocity [Mudry et al., 1994]. With the flux conservation equations, neglecting the volume variations inside the reservoir, the spring yield (QS) and the spring water content (CS) can be described for two water periods:

- for low water periods QS = QR + QI (Eq. 1)

- for high water periods QSCS = QR CR + QI CI (Eq. 2) 
with $\mathrm{QR}$, the yield of the spring in the period of low water table, CR the water content at the spring during a period of low water table, QI, the infiltration yield and CI, the water content of rainfall. By integrating Eq. 2 over time, for $\mathrm{CI}=0$, we can assess the water volume that provokes a dilution

observed at the spring during a rain event (Equation 3):

$$
V_{\text {infiltrated }}=\sum_{t}^{0} \frac{\left(\mathrm{C}_{\mathrm{R}}-\mathrm{C}_{\mathrm{S}}\right)}{\mathrm{C}_{\mathrm{S}}} \mathrm{Q}_{\mathrm{R}} d t
$$

(Eq. 3) with t, the end time of the flood.

For each spring the percentage of infiltrated water is determined with the infiltrated volume (Eq. 3) and compared to rainfall measurements and to the infiltration areas. The rain heights are measured at the "La Clapière" meteorological station multiplied by the infiltration area estimated with mapping result in a rainfall volume for a flood. The ratio between the infiltrated volume and rainfall gives information on the percentage of water that arrived to the spring after a flood. As the sulfates in water have a pyrite or evaporite origin, sulfate content can be neglected in the rain water which is therefore a relevant marker of infiltration [Cappa et al.,2004].

\section{RESULTS: CORRELATION BETWEEN GRAVITATIONAL STRUCTURES AND SLOPE HYDROGEOLOGY}

\section{Geometry and geological characteristics of the water reservoirs}

The geographical relation between spring location and geology defines three principal types of aquifer (fig. 1a). The glacial deposits and the screes are superficial aquifers of reduced size. The Jurassic and the Triassic rocks constitute a second type of aquifer, where the permeability contrast between sedimentary rocks and metamorphic rocks explains the location of the springs outflowing around this contrast zone. The third type of aquifer is the gneissic rock, which springs are located near fractures or faults. If we focus on the geometry of the gneiss aquifers, most of the springs are located at the middle of the hillslope close to the unstable structures. The decompressed areas (scarps and trenches; fig. 1 and fig. 2) influence the draining system and may explain the location of springs under the trenches, such as for the Malbosc trenches (fig. 2d). The areas of decompressed gneiss correspond to recharge area of springs. The characteristics of the aquifers geometry can be detailed at various scales. The cliffs of "Valabres" are an interesting zone too, because the Tinée River crosses the geological regional structures. It is possible to observe a deep cross section of the structures. The bottom of the main double ridge is drained by one of the most important spring of the country (fig. 2a, spring no 179) with a minimum yield of 5 l.s-1. A schematic view of the gorge shows the N180o double ridge which extends about 2 $\mathrm{km}$ in the massif. The zone around the trench is highly fractured. A decompressed area is observed between a vertical tectonic fracture towards the north-west and a fracture dipping about 45o towards the south-east. The spring is located at the convergence of the main fractures, which is the boundary between a collapsed zone and the fractured gneiss. Some trenches (fig. 2b) are cut in the "La Clapière" main scarp and show cracks filled with colluviums, sands and blocks of various sizes. The bedding is warped, showing that sedimentation occurred while gravitational movement was active and these trenches extend under the slope because of the gravitational reactivation of a tectonic fault. Tilted rocks open the fractures in the upper part of the trenches. These perched waters, observed over $800 \mathrm{~m}$ are perennial, flow in unstable structures, parallel to the valley axis and perpendicular to the gravitational toppling directions (fig. 2). These water reservoirs, structured by gravitary features are interconnected via the tension crack network. The toppled zone is a highly fractured area where tension cracks create linear drains that induce a permeability contrast. An intermediate aquifer is also clearly identifiable on the hillslopes. The sliding mass takes place on the border of the decompressed area and creates a new water pathway near the valley. The movement increases the gneiss weathering, observable for example in the "La Clapière" landslide (fig. 2b, spring no 14, spring no 15) or in a dormant landslide located in the "Claï Haute" area (fig. 2c, spring no209, spring no 211). In these two areas, the cross sections (fig. 1c, fig. 2c) indicate that destructured sliding rocks bypass the flow of the perched water in the trench network. The bypassing waters outflows at the foot of the moving masses. Finally, in the Malbosc hillslope (fig. 2d) a gallery was drilled and an important water inflow was observed $100 \mathrm{~m}$ down to the trenches. These observations prove that these aquifers have a continuity with depth around the fractures. All these observations can be reported on a hydrogeological cross-section (fig. 1c). The represented faults are only the faults with a major gravitational reactivation. Throughout the valley, the structures reveal an extensional movement that explains the decompression of the upper part of the hillslope bounding the perched flows.

\section{Analysis of origin of infiltration waters deduced from spatial variations of water chemistry}

To discuss the flows origin, water chemistry of springs is compared to the hydrogeological map (fig. 1b). The spatial variability of the water content is presented with a ternary $(\mathrm{Mg}-\mathrm{Na}-\mathrm{Cl})$ plot. The close correlation between magnesium water type and springs sampled in the Triassic and Jurrasic covers proves that magnesium is a marker of the Triassic-Jurassic aquifer, originating from dolomite mineral dissolution (fig. 3a). The magnesium content is higher than $0.2 \mathrm{mmol} . \mathrm{L}-1$; at the opposite, the springs sampled in gneiss never exceed a magnesium 
content of $0.15 \mathrm{mmol} \cdot \mathrm{L}^{-1}$. Relatively to magnesium, the sodium $(\mathrm{Na})$ content is more present in the superficial water and in the decompressed aquifer; this feature may be explained by the plagioclase weathering.

Some springs located in the decompressed gneiss have a magnesium water type that demonstrates a connection of the gneiss decompressed aquifers with the Triassic-Jurassic aquifer.

Finally, chlorides ions $(\mathrm{Cl})$ are more present in the springs of the fractured aquifer located in the bottom of the valley (fig. 3a, fig. 3b), which is apparently not connected to the instability features (fig. 1b). A close correlation between sodium and chloride in water from the decompressed aquifer can be linked to weathering dynamics in the decompressed gneisses. The springs sampled in the fractured aquifer have higher chloride concentrations and reveal a different chloride weathering dynamic in gneiss or a different origin. Thus, chlorides enable to prove connection of a spring with the fractured aquifer or with flows within decompressed areas.

According to chemistry measurements, a cross-section (fig. 1c) can be drawn; this cross-section differentiates a fractured aquifer at the bottom of the valley and perched structures in the upper hillslopes driven by unstable structures. The two water types suggest two different aquifers within the same rock mineralogy. The hydrochemical contrast, during low water table periods, argues the presence of two disconnected behaviours because low chlorides contents are observed in the perched waters.

\section{Destabilization effect on infiltrated water}

The specific yield is estimated by hydrochemistry (tabl. I) for the springs classified as draining a fratured aquifer and for the springs classified as draining a decompressed aquifer. Figure 3 shows an increase of 2 order of magnitude of the specific yield for the decompressed areas compared to the fractured areas. These specific yields indicate that the collapsed structures increase strongly the infiltrated water volume compared to the stable fractured slopes with high potential runoff and lower water infiltrated volumes. The percentage of water drained by the springs during a flood (calculated with Eq. 3) is applied to the "Valabres" hillslope and the "La Clapière" landslide. Applied to the Luicetta spring (fig. 2a; no 179) which drains a large double ridge of the "Valabres" hillslope (tabl. II), $\sim 40 \%$ of the water fallen in the ridge passes through the aquifer during the flood. At the opposite, in the recharge area of the "La Clapière" hillslope, a maximum of $10 \%$ of rainfall passes through the perched aquifer during the flood. The uncertainty on these percentages is estimated at $\pm 15 \%$ related to the hypothesis on the type of infiltration, the seasonal evolution of evapotranspiration, and for "La Clapière" hillslope to a part of water flowing directly into the alluvium deposits. This analysis reveals that 10 to $50 \%$ of rainwater can be drained by the geomophological structures.

\section{Destabilization effect on the water flows}

The response of the fractured aquifer ("Valabres" gallery) to the 2003, 01/11 flood indicates a dilution phenomena and flow velocities of 1.10-5 m.s-1 (fig. 4; tabl. III). The dilution curves monitored at spring no 43 and spring no 179 in the toppling and decompressed aquifer present high flow velocities from 5.10-4 to 5.10-3 m.s-1 (tabl. III) and a piston flow-type (fig. 4). In the "La Clapière" landslide, the dilution curves have different shapes related to these locations. Spring no 15 presents a high velocity of 10-3 m.s-1 and a piston flow-type; the water drains a highly destructured trench. Spring no 14 shows an immediate response with a residence time of 5.10-4 m.s-1 and a low dilution that displays a homogeneization caused by a large density of fractures within this part of

the landslide.

These four springs (fig. 4), representative of different geomorphological contexts, demonstrate that water flows evolve with slope deformation, with a decrease of residence time and an evolution of the flow types from a dilution phenomena in the fractured hillslopes to piston flows in the decompressed hillslopes.

\section{DISCUSSION: A CONCEPTUAL MODEL OF GROUNDWATER FLOWS IN UNSTABLE HILLSLOPES}

\section{Conceptual model}

Figure 5 proposes a synthesis of water flows within the hillsope and indicates the complex relationship between water infiltration and geomorphological context. With the toppling and opening of the fractured rocks, the draining role of the trenches increases. The correlation between the hydrogeological map and the geomorphological map (fig. 1 and fig. 2) proves that water is drained by fractures and counterscarps

which are opened by deformation and allow flows perpendicular to the topographic slope. The trenches and the counterscarps tend to limit runoff and facilitate groundwater infiltration. Water is drained in these structures and outflows in the middle of the slope, at the bottom of the gravitational structures, where decompression does not occur. The landslides occur mainly at the border of the decompressed areas. Water in the landslide can originate from upper parts of the hillslope (fig. 1c); the three groups of springs (toe of the landslide, fractured rocks and decompressed areas) are draining most of the infiltrated water (fig. 5). In a stable fractured gneiss the average permeability may range from $1.10-9$ to $1.10-4$ m.s- 1 and the maximum porosity is less than $1 \%$ [Guimera and 
Carrera, 2000]. In the upper part of the unstable slope of the study site, the porosity increases with the filling of the trenches by weathered materials (fig. 2b) and can reach the porosity of a sand (around 20\%). Maréchal [1998] had computed hydraulic conductivity of Alpine gneisses ranging between 2.7.10-8 m.s-1 (for fractured gneiss) to 1.6.10-4 m.s-1 (for decompressed areas) and assumes the presence of perched water in a more permeable decompressed rock. The observed contrasted hydrochemical behaviour (fig. 3) indicates that the perched flows are not influenced by water from the fractured rock. Moreover, referred to the variability of spring elevations in the slope, the hypothesis of a single saturated perched zone implies a hydraulic gradient of $50 \%$ that is difficult to argue in a highly diffusive context. Thus a conceptual model with perched saturated zones disconnected from the fractured aquifer seems more appropriate.

In large rock slope failures such as the Hope slide (British Columbia, Canada; Brideau et al. [2005]), such type of flows were observed with seepages zones (up $800 \mathrm{~m}$ above the valley floor) draining the slip surfaces. Examples of outflows of lateral flows in the middle part of hillslope and of a disconnexion between the local aquifer and the regional water tables have also been identified in the Hubei Province in the Three Gorge dam weathered granite [Zhang et al., 2000] or in the Highlands of Scotland where slope deformation creates fracture facets, allowing lateral groundwater percolation and progressive creep [Jarman, 2006].

\section{Evolution of water flow paths in the slope}

During the glacial period, the hillslope is considered without failure (fig. 6a). For similar deep-seated deformation observed in metamorphic rocks in the Alps, long-term evolution begins after glacier melting. Glacier melting unloads the slope which consequence is the formation of failure surfaces [Agliardi et al., 2001] such as hypothesised at the "Valfurna" or the "Rosone" landslides [Forlati et al., 2001]. The decompression linked to glacier melting enables a decompression in the upper part of the slope. In some places, the deformation can be accommodated by toppling, that opens the tensile cracks and decompresses some zones, creating trenches (fig. 6b). This stage is similar to the "Sechilienne" landslide [Vengeon, 1998]. Toppling creates trenches progressively filled with a granular matrix (fig. 6c). In the "La Clapière" landslide, the landslide recuts the trenches (fig. 2b) and toppling evolves towards the landslide in the border of the decompressed areas. This relation between landslides and decompressed areas is confirmed for all the landslides observed in the valley (fig. 1; fig. 2). The hydrogeological observations in the Upper Tinée Valley indicate that the evolution of deformation modifies the groundwater flows (fig. 4). The more the toppling is developped, the more important is the drained water volume in the perched aquifer (tabl. I; tabl. II). When the yearly cyclic hydromechanical effect had damaged sufficiently the material within the perched aquifer, a landslide may occur that bypasses the water flow parallel to the slope (fig. 1c) and decreases the water pressure in the trenches. After failure, the infiltration periods occurring upper in the landslide can create significant hydromechanical effects in the moving-mass.

\section{Evolution of water diffusivity in the slope}

The hydraulic properties of the gneiss evolve with deformation (fig. 4): (i) the transit time decreases; (ii) the flow type changes from a dilution-type flow to a piston-type flow; (iii) the seasonal variation of the hydraulic head decreases because fractures fillings have a stronger storage capacity (fig. 2a, fig. 2b, fig. 2c; cross-sections). In fractured hillslopes or in slopes with tensile cracks, the storage capacity in the middle part of the slope is low. The seasonal variability of water infiltration may create strong water pressures with low water volumes; the slope is therefore subjected to a high hydromechanical coupling (fig. 6a; fig. 6b) as in stable fractured rock [Rutqvist and Stephansson, 2003]. For example, the failure observed at point 1 at "La Clapière"

landslide (fig. 6b) is affected by changes in water pressures in the saturated zone. In the "Séchilienne" landslide [Vengeon, 1998] or in the "Campo Vallemaggia" landslide [Bonzanigo, 1999], numerical calculations link effective strain in the landslide with seasonal variability of water pressures. With toppling, weathered

materials fill tensile cracks that create a storage zone. The saturated zones of the slope become disconnected from the saturated zones of the perched aquifer (fig. 1c; fig. 3) and the water pressure distribution is modified. The variability of the seasonal hydrostatic pressure decreases relatively to the fractured slopes, but is applied higher in the slope (fig. 6c). Point 1 (fig. 6c) is not submitted to hydrostatic water pressures because it is located in the unsaturated zone. The rupture propagation at this point is influenced by water loads and pressure in the tensile cracks located upper in the slope. The seasonal variability of water infiltrated in the perched aquifer can influence the slope stability, loading the middle part of the slope; these conditions may increase the possibilities of failures by the tilt of large rock volumes from the bottom of the perched aquifers to the foot of the hillslope [Guglielmi et al., 2005] (fig. 6c).

\section{CONCLUSION}

In unstable hillslopes, groundwater flows are continuously modified because long-term slope deformation and toppling continuously changes the geometry of the aquifer. Growing fractures create new drains that may increase the hydraulic properties of the decompressed volumes. The main part of the infiltrated water in the 
hillslope is drained by these decompressed volumes in a perched zone that outflows at the middle of the slope. When a landslide occurs, it may cut these drains and bypass the groundwater flowing in the trenches.

It is therefore necessary to study the entire hillslope to understand the water transfers from the upper part of the slope to the slip surface, to take into account the effect of the perched water on the landslide kinematics, and to understand the hydromechanical interactions within the landslide.

Toppling may create voids filled progressively with colluviums that create a high hydraulic conductivity gradient between the trenches and the gneissic rock. The saturated zone of the hillslope is therefore disconnected from the saturated zone of the perched aquifer, and the water pressure distribution is modified. With the progressive destabilization of the slope, the hydromechanical coupling evolves from high water pressures in the low storage capacity fractures to a potential high water loading in the high storage capacity zones in the upper parts of the hillslope.

Acknowledgements. - Support of this work was partially provided by the French National Institute for Universe Sciences (INSU) in the framework of the 'ACI - Prévention des Catastrophes Naturelles' Program (Project SAMOA) and by the European Union through the RETINA Project. The authors sincerely thank the Centre d'Etude Technique de l'Equipement (CETE) of Nice for its collaboration. The Mercantour National Park is kindly acknowledged for its authorization to conduct this study within its area. The authors sincerely thank Pr. Olivier Fabbri for his constructive comments. Finally, the authors are grateful to two anonymous reviewers for their improvements of the manuscript.

\section{References}

AGLIARDI F., CROSTA G. \& ZANCHI A. (2001). - Structural constraints on deep-seated slope deformation kinematics. - Eng. Geol., 59,

83-102.

BIGOT-CORMIER F., POUPEAU G. \& SOSSON M. (2000). - Dénudations différentielles du massif cristallin externe alpin de l'Argentera

(Sud-Est de la France) révélées par thermochronologie sur les traces de fission (apatites, zircons). $-C$. $R$. Géosciences, 330,363-370.

BLAVOUX B. \& MUDRY J. (1983). - Séparation des composantes de l'écoulement d'un exutoire karstique à l'aide des méthodes physico-chimiques. - Hydrogéologie, 4, 269-278.

BONZANIGO L. (1999). - Lo slittamento di Campo Vallemaggia. - PhD Thesis, Univ. of Zürich, Switzerland, 219 p.

BONZANIGO L., EBERHART E. \& LOEW S. (2001). - Hydromechanical factors controlling the creeping Campo Vallemaggia landslide. In: Proc. Int. Symp. on Landslides: Causes, Impacts and Countermeasures,

Davos, Switerland. - Verlag Gluckauf GmbH, Essen, 9-12. BRIDEAU M.-A., STEAD D., KINAKIN D. \& FECOVA K. (2005). - Influence of tectonic structures on the Hope Slide, British Columbia, Canada. - Eng. Geol., 80, 242-251.

CAPPA F., GUGLIELMI Y., SOUKATCHOFF V., MUDRY J., BERTRAND C. \& CHARMOILLE A. (2004). - Hydromechanical modeling of a large moving rock slope inferred from slope levelling coupled to spring longterm hydrochemical monitoring: example of the La Clapière landslide (southern Alps, France). - J. Hydr., 291, 67-90.

CRUDEN D.M. \& VARNES D.J. (1996). - Landslide types and processes. In: Landslides investigation and mitigation, Transportation Research Board, Special Report 247. - National Academy of Sciences. Washington DC., USA, 36-75.

DELTEIL J., STEPHAN J.-F. \& ATTAL M. (2003). - Control of Permian and Triassic faults on Alpine basement deformation in Argentera massif (external southern French Alps). - Bull. Soc. géol. Fr., 174, 481-496.

DUBAR M. \& STEPHAN J.-F. (2001). - Le Glaciaire de la Tinée: calibrage, chronologie et impact morphodynamique. - Proc. Workshop PNRN Mouvements Gravitaires Alpins, Nice, France, Univ. Nice, 1-7.

DYSLI M. (1998). - Of bearing capacity of roads during thaw and debris flows in mountain permafrost: The same phenomenon. In: Proc. Permafrost and Actions of Natural and Artificial Cooling, Paris- Orsay, France.Institut International du Froid, Paris, 208-216

FAURE-MURET A. (1955). - Etudes géologiques sur le massif de l'Argentera- Mercantour et ses enveloppes sédimentaires, mémoires à l'explication de la carte géologique détaillée. - Thèse de Doctorat, Univ. Paris 6, France, $336 \mathrm{p}$.

FORLATI F., GIODA G. \& SCAVIA C. (2001). - Finite element analysis of a deep-seated slope deformation. Rock Mech. \& Rock Eng., 34, 135-159. 
FURUYA G., SASSA K., HIURA H. \& FUKUOKA H. (1999). - Mechanism of creep movement caused by landslide activity and underground erosion in crystalline schist, Shikoku Island, southwestern Japan. - Eng. Geol., 53, 311-325.

GUGLIELMI Y., CAPPA F. \& BINET S. (2005). - Coupling between hydrogeology and deformation of mountainous rock slopes: insights from La Clapière area (Alpes Maritimes). - C.R. Geosciences, 337, 11541163.

GUGLIELMI Y., VENGEON J.-M., BERTRAND C., MUDRY J., FOLLACCI J.-P. \& GIRAUD A. (2002). Hydrogeochemistry: an investigation tool to evaluate infiltration into large moving rock masses (case study of the La Clapière and Séchilienne alpine landslides). - Bull. Eng. Geol. \& Environ., 61, 311-324.

GUIMERA J. \& CARRERA J. (2000). - A comparison of hydraulic and transport parameters measured in lowpermeability fractured media. - J. Contaminant Hydrol., 41, 261-281.

JARMAN D. (2006). - Large rock slope failures in the Highlands of Scotland: characterisation, causes and spatial distribution. - Eng. Geol. (in press).

JIAO J.J. \& MALONE A.W. (2000). - An hypothesis concerning a confined groundwater zone in slopes of weathered igneous rocks. In: Proc. Slope Hazards and their Prevention, Hong Kong. - Balkema, Rotterdam, 165-170.

JULIAN M. \& ANTHONY E. (1996). - Aspects of landslide activity in the Mercantour Massif and the French Riviera, southeastern France. - Geomorphology, 15, 275-289.

MARECHAL J.C. (1998). - Les circulations d'eau dans les massifs cristallins alpins et leurs relations avec les ouvrages souterrains. - Thèse de Doctorat, Ecole Polytechnique Fédérale de Lausanne, Lausanne, Suisse, 295 p. MEIJER A. (2002). - Conceptual model of the controls on natural water chemistry at Yucca Mountain, Nevada. - Applied Geochem., 17, 793-805.

MUDRY J. (1987). - Apport du traçage physico-chimique naturel à la connaissance hydrocinématique des aquifères carbonatés. - Thèse de Doctorat, Univ. Franche-Comté, Besançon, 378 p.

MUDRY J., LASTENNET R., PUIG J. \& BLAVOUX B. (1994). - Use of natural tracing to understand how an aquifer works. Basic and applied hydrogeological research in French karstic areas. - Proc. COST Action 65, Brussels, Belgium, 27-53.

RUTQVIST J. \& STEPHANSSON O. (2003). - The role of hydromechanical coupling in fractured rock engineering. - Hydrogeology J., 11, 7-46.

TULLEN P. (2002). - Méthodes d'analyses du fonctionnement hydrogéologique des versants instables. - Thèse de Doctorat, Ecole Polytechnique Fédérale de Lausanne, Lausanne, Suisse, 192 p.

VENGEON J. (1998). - Déformation et rupture des versants en terrain metamorphique anisotrope. Apport de l'étude des Ruines de Séchilienne. - Thèse de Doctorat, Univ. J. Fourier, Grenoble, France, 180 p.

VERBUNT M., GURTZ J., JASPER K., LANG H., WARMERDAM P. \& ZAPPA M. (2003). - The hydrological role of snow and glaciers in alpine river basins and their distributed modeling. - J. Hydrol., 282, 36-55.

WEN B.P., DUZGOREN-AYDIN N.S. \& AYDIN A. (2004). - Geochemical characteristics of the slip zones of a landslide in granitic saprolite, Hong Kong: implications for their development and microenvironments. Environ. Geol., 47, 140-176.

ZHANG J., JIAO J.J. \& YANG J. (2000). - In-situ rainfall infiltration studies at a hillside in Hubei Province, China. - Eng. Geol., 57, 31-38. 


\section{FIGURES AND TABLES:}
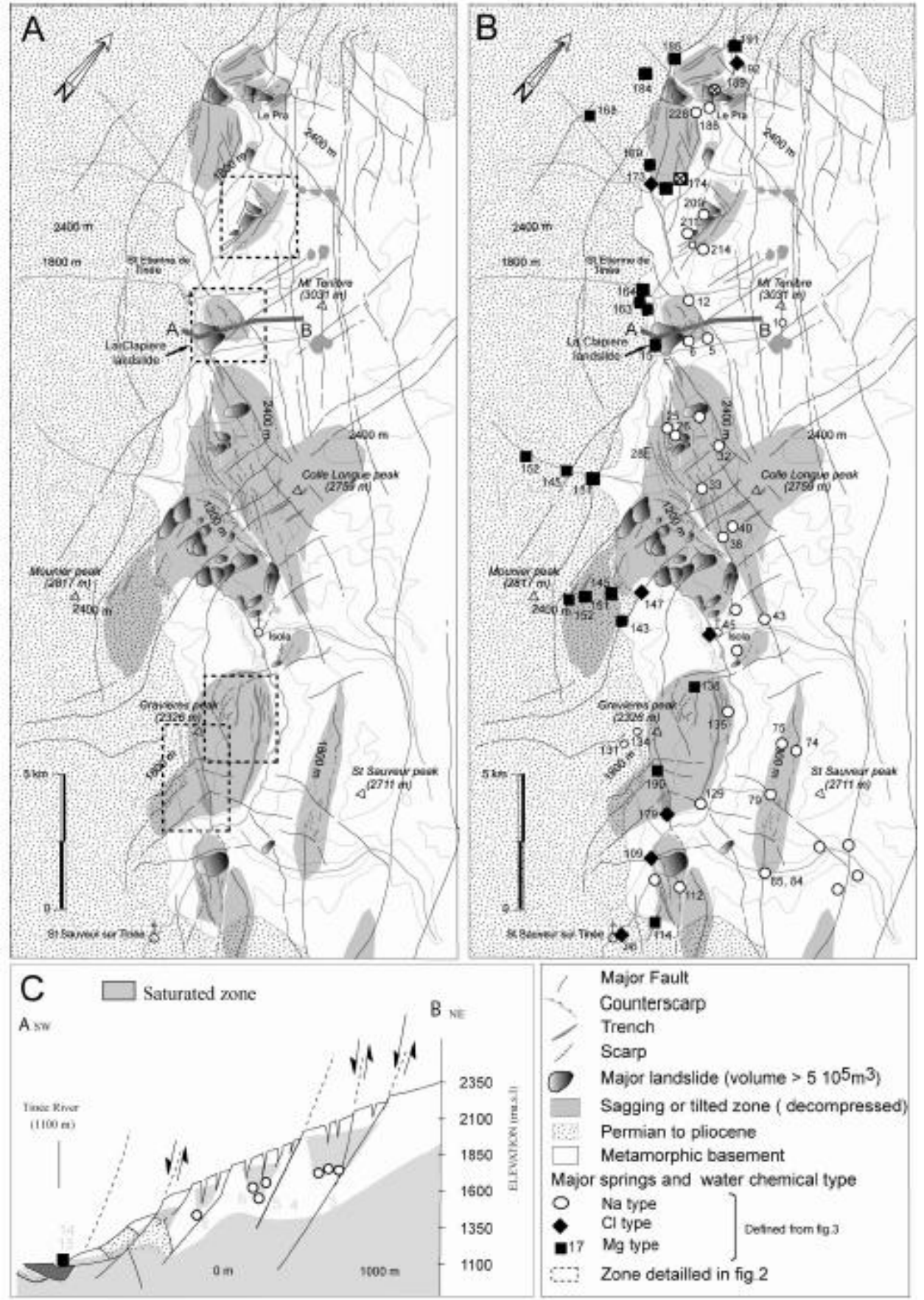

FIG. 1. - Schematic map of the Upper Tinée Valley. a) Geomorpholocical map. b) Hydrogeological map. c) Hydrogeological cross-section of the "La Clapière" unstable slope. 



FIG. 2. - Hydrogeological details of representative unstable areas. a) "Valabres" hillslope. b) "La Clapière" hillslope. c) "Claï Haute" hillslope; d). "Malbosc" hillslope. 


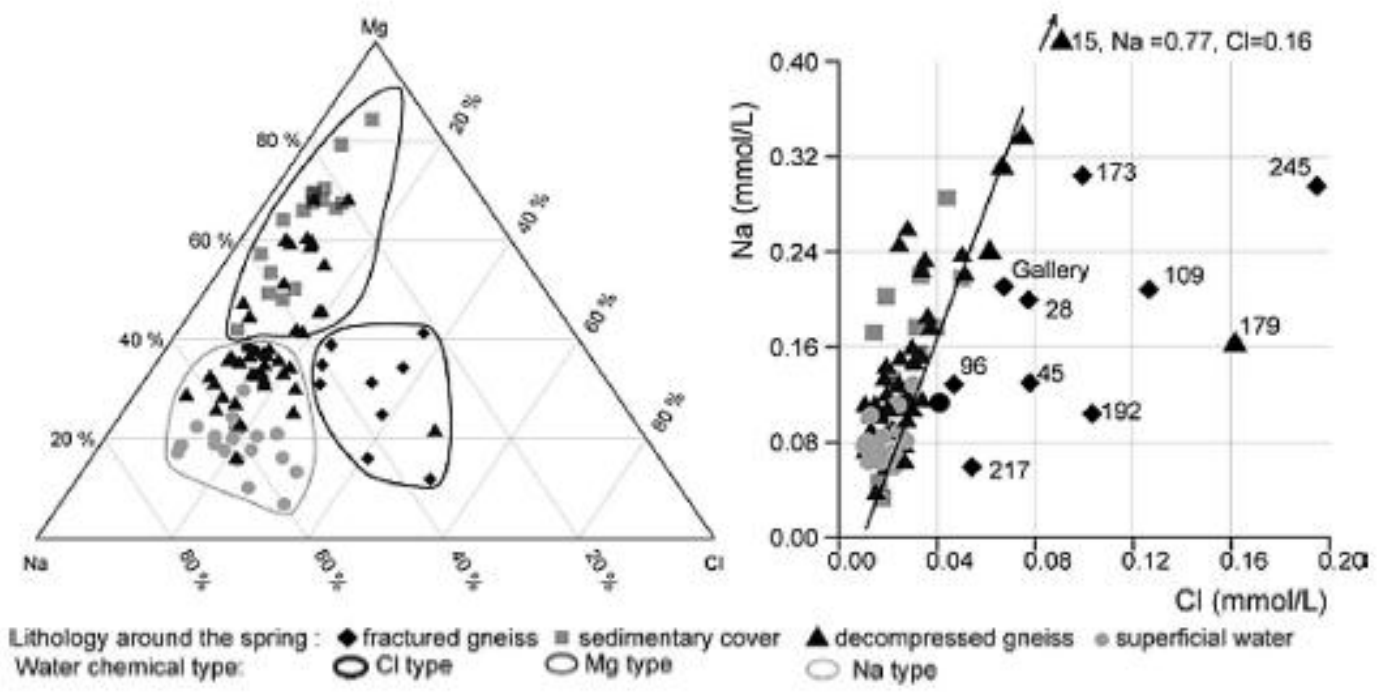

FIG. 3 - Water quality of the springs sampled in the Upper Tinée Valley (August 2003). a) Hydrochemistry ternary plot; b) Na-Cl graph.

\begin{tabular}{|c|c|c|c|c|}
\hline Aquifer type & Spring & Yield $\left(\mathbf{I s}^{-\mathbf{1}}\right)$ & Recharge area $\left(\mathbf{k m}^{2}\right)$ & Specific yield $\left(\mathbf{l} \mathbf{s}^{-1} \cdot \mathbf{k m}^{-2}\right)$ \\
\hline Fractured & $\mathrm{n}^{\mathbf{0}} 245$ & $1.10^{-3}$ & 0.9 & 0.001 \\
\hline Fractured & $\mathrm{n}^{\mathbf{0}} 192$ & $3.10^{-3}$ & 0.5 & 0.007 \\
\hline Fractured & $\mathrm{n}^{\circ} 96$ & $3.10^{-3}$ & 0.4 & 0.010 \\
\hline Decompressed & $\mathrm{n}^{\circ} 5$ & 0.20 & 0.5 & 0.40 \\
\hline Decompressed & $\mathrm{n}^{\circ} 11$ & 0.11 & 0.3 & 0.40 \\
\hline Decompressed & $\mathrm{n}^{0} 129$ & 0.12 & 1.5 & 0.10 \\
\hline Decompressed & $\mathrm{n}^{0} 211$ & 1.50 & 1.3 & 1.20 \\
\hline
\end{tabular}

TABLE I. - Specific yield estimated for fractured and decompressed aquifers.

\begin{tabular}{|c|c|c|c|c|c|}
\hline & $\mathbf{P}(\mathbf{m m})$ & $\mathrm{V}_{\mathrm{IS}}\left(\mathrm{m}^{3}\right)$ & $\mathrm{V}_{\text {OUT }}\left(\mathrm{m}^{3}\right)$ & $\mathrm{I}(\mathrm{mm})$ & Water drained by fracture $(\%)$ \\
\hline \multicolumn{6}{|l|}{ Luicetta, spring n' 179} \\
\hline $01 / 11 / 2003$ & 118 & 11800 & 4539 & 45 & $38 \%$ \\
\hline $23 / 02 / 2004$ & 55 & 5500 & 2460 & 25 & $45 \%$ \\
\hline $03 / 12 / 2003$ & 65 & 6500 & 2399 & 24 & $37 \%$ \\
\hline \multicolumn{6}{|c|}{ La Clapière, springs n' $5,6,7,8,12,15$ (Infiltration area $=3,500000 \mathrm{~m}^{2}$ ) } \\
\hline $29 / 04 / 1996$ & 50 & 150000 & 15457 & 5 & $10 \%$ \\
\hline $07 / 09 / 2000$ & 8 & 28000 & 1659 & 0.5 & $6 \%$ \\
\hline
\end{tabular}

TABLE II. - Water balance for two decomprimed aquifers. 


\begin{tabular}{|l|c|c|c|}
\hline \multicolumn{1}{|c|}{ Characteristics } & Draining trench & Decompressed zone & Fractured aquifer \\
\hline Spring name & La Clapière $\mathrm{n}^{\circ} 5$ & Luicetta $\mathrm{n}^{\circ} 179$ & Galerie EDF \\
\hline Number of events analysed & $\mathrm{n}=15$ & $\mathrm{n}=3$ & $\mathrm{n}=3$ \\
\hline Recharge area $\left(\mathrm{m}^{2}\right)$ & $50000+-5000$ & $100000+-10000$ & 57 \\
\hline $\begin{array}{l}\text { Sulfate concentration during periods } \\
\text { of low water table }\left(\mathrm{mg} . \mathrm{L}^{-1}\right)\end{array}$ & 39 & 20 & from 10 to 20 \\
\hline Estimated mean transit time (days) & from 1 to 8 & from 1 to 4 & from $1.10^{-5}$ to $1.10^{-4}$ \\
\hline Estimated transit speed $\left(\mathrm{m} . \mathrm{s}^{-1}\right)$ & from $5.10^{-3}$ to $5.10^{-4}$ & from $2.10^{-2}$ to $8.10^{-3}$ & \\
\hline
\end{tabular}

TABLE III. - Hydrogeological characteristics of three springs representative of a draining trench, of a decompressed area and of a fractured aquifer.

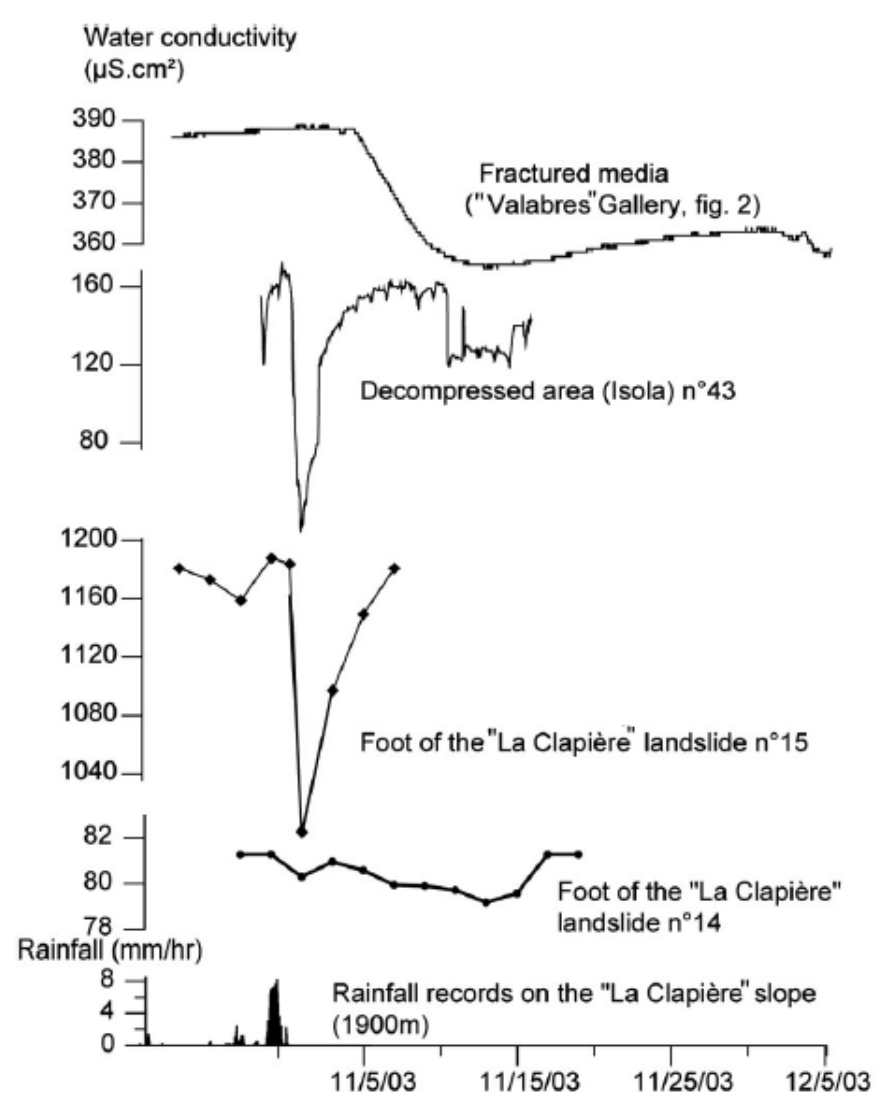

FIG. 4 - Evolution temporelle de la conductivité de quatre sources suite à l'épisode de crue du 01/11/2003. 


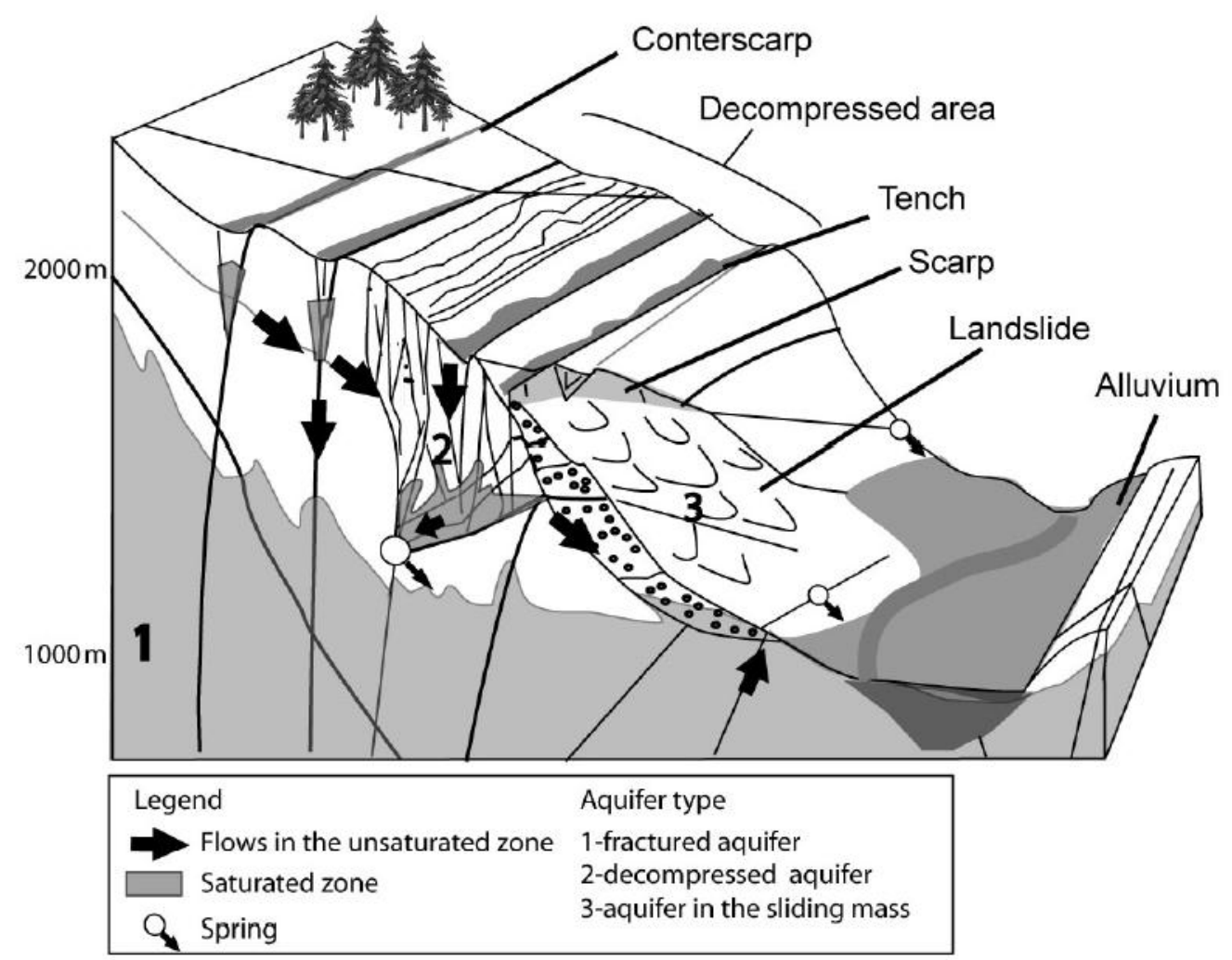

FIG. 5. - Conceptual model of groundwater flows in unstable rock slopes, derived from the analysis of hillslopes in the Upper Tinée Valley

(South-East French Alps).

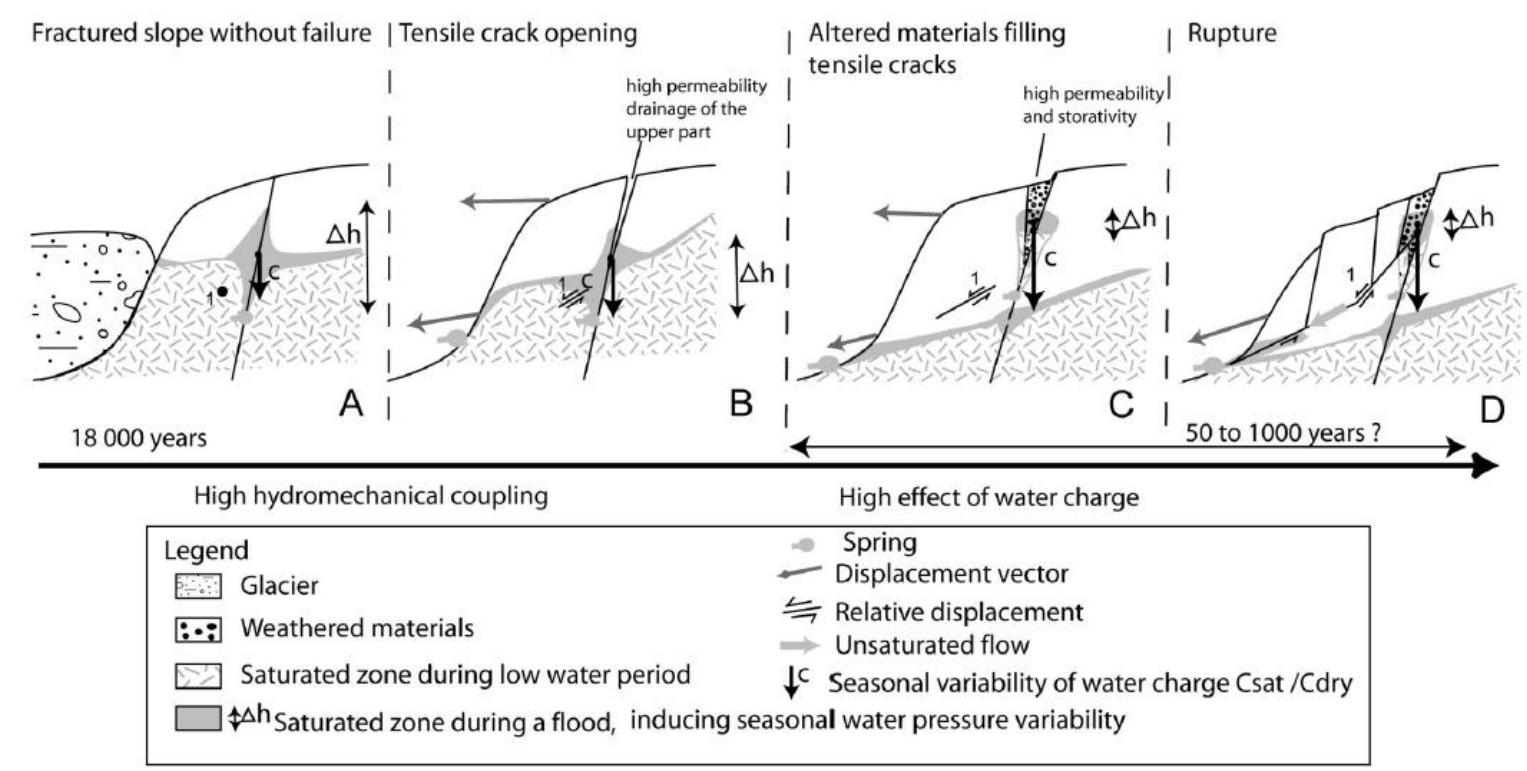

FIG. 6. - Long-term effect of the coupling between water flows, hillslope deformation and landslides. 